\title{
Influence of lipoxygenase activity and calcium and potassium contents on bitter pit occurrence in commercial apple cultivars
}

\author{
Marzena Wińska-Krysiak, Barbara Lata
}

Laboratory of Basic Sciences in Horticulture

Warsaw University of Life Sciences

Nowoursynowska 159, 02-776 Warsaw, Poland

e-mail: marzena_winska_krysiak@sggw.pl

\begin{abstract}
The content of calcium and potassium and lipoxygenase (LOX) activity as well as the expression of LOX encoding gene in the fruit of apple cultivars that are both susceptible and resistant to bitter pit were evaluated. Fruits were collected and analyzed after harvest in the 2004 growing season and again after four months of common cold storage. The main reason was the explanation of relationship between those LOX activity and $\mathrm{K}: \mathrm{Ca}$ ratio on bitter pit occurrence during storage. The biggest differences between the tested cultivars were noted in LOX activity and Ca content, followed by $\mathrm{K}: \mathrm{Ca}$ ratio and the lowest potassium content. The cultivars that were resistant and susceptible but without symptoms of bitter pit exhibited higher calcium content compared to cultivars with signs of bitter pit, and with a drop in LOX activity after storage. A negative correlation was found between LOX activity and Ca content and a positive correlation was found between $\mathrm{K}: \mathrm{Ca}$ ratio and LOX activity.
\end{abstract}

Key words: Malus domestica Borkh., calcium, K:Ca ratio, lipoxygenase activity

\section{INTRODUCTION}

The chemical composition of fruit is determined by several factors, both environmental and genetic (Chiu and Bould 1977, Coccuci et al. 1990, Saure 1996, Drazeta et al. 2004). Fruits of low $\mathrm{Ca}$ content and high $\mathrm{K}$ content, and consequently, a high $\mathrm{K}: \mathrm{Ca}$ ratio, are susceptible to bitter pit occurrence. Moreover, the development of this disorder is also influenced by storage conditions and the activity of the enzymes involved in fruit respiration. Special attention should be paid to LOX, which increase is frequently observed during storage, especially in cultivars with high $\mathrm{K}: \mathrm{Ca}$ ratios (Marcelle 1989).

The aim of this study was to investigate the relationship between $\mathrm{Ca}$ content, $\mathrm{K}$ : $\mathrm{Ca}$ ratio and $\mathrm{LOX}$ activity and bitter pit development in cultivars of low and high susceptibility to that disease.

\section{MATERIAL AND METHODS}

Plant material and sample preparation

The research was performed on apples harvested in the 2004 vegetation season in an orchard located in central Poland and cultivated according to standard horticultural practices. The soil was maintained as herbicide strips with rows of trees and sward between them. Mean temperatures and rainfall in 2004 season are presented in Table 1. The plant materials used were the fruits of eight cultivars, both susceptible ('Šampion', 'Cortland', 'Mutsu', 'Ligol') and resistant ('Gala', 'Idared', 'Alwa', 'Gloster') to bitter pit. Fruits for analysis were collected twice: at harvest and after four months of common cold storage. Each sample consisted of 8-mm thick vertical slices derived from five fruits (one replication). Samples were immediately frozen in liquid nitrogen and stored at $-80^{\circ} \mathrm{C}$ until biochemical and molecular analyses were 
Table 1. The air temperatures $\left({ }^{\circ} \mathrm{C}\right)$ and rainfall $(\mathrm{mm})$ for the field of the Warsaw-Wilanow Station in the year 2004

\begin{tabular}{|c|c|c|c|c|c|c|c|}
\hline & \multirow{2}{*}{ Year } & \multicolumn{6}{|c|}{ Month } \\
\hline & & IV & $\mathrm{V}$ & VI & VII & VIII & IX \\
\hline Mean monthly temperature $\left({ }^{\circ} \mathrm{C}\right)$ & 2004 & 9.3 & 12.8 & 16.6 & 18.6 & 19.8 & 14.5 \\
\hline \multirow[t]{2}{*}{ Rainfall (mm) } & 2004 & 60 & 53 & 39 & 58 & 52 & 20 \\
\hline & Mean for $1971-2000$ & 35 & 51 & 71 & 73 & 59 & 49 \\
\hline
\end{tabular}

conducted. Directly before analysis, apple tissue was ground to a fine powder in liquid nitrogen. Chemical and molecular analyses were performed in 4 replicates for each cultivar.

\section{Calcium and potassium contents and mean fruit weight}

Samples were dried at $65^{\circ} \mathrm{C}$ for $24 \mathrm{~h}$ and then at $105^{\circ} \mathrm{C}$ for $3 \mathrm{~h}$, and mineralized in a combustion furnace. Calcium content was determined by an inductively-coupled plasma spectrometer, whereas potassium content was determined by photometer. The $\mathrm{Ca}$ and $\mathrm{K}$ concentrations were reported on a dry-mass basis. The mean fruit weight of the cultivar was obtained from 10 apples.

\section{LOX activity measurement}

LOX activity was measured by monitoring the increase in absorbance at $234 \mathrm{~nm}$. The reaction was carried out for $4 \mathrm{~min}$ at $25^{\circ} \mathrm{C}$. The plant tissue was homogenized in a $0.2 \mathrm{M}$ boric buffer, $\mathrm{pH} 7.0$ containing $0.2 \%$ PVPP and centrifuged at $15,000 \mathrm{~g}$ for 20 minutes at $4{ }^{\circ} \mathrm{C}$. The reaction mixture contained $100 \mu \mathrm{l}$ of plant extract, $0.5 \mathrm{ml}$ linoleic acid as substrate $(25 \mu 1$ of linoleic acid dissolved in $0.5 \mathrm{ml}$ of methanol and $37.5 \mu \mathrm{l}$ of Tween 20 , diluted to $50 \mathrm{ml}$ with water; prior to analysis, $4.2 \mathrm{ml}$ of linoleic acid/methanol solution was mixed with $20.8 \mathrm{ml}$ of $0.2 \mathrm{M}$ boric buffer $\mathrm{pH} 8.0$ ) and $0.2 \mathrm{M}$ boric buffer $\mathrm{pH} 8.0$ in a final volume of $1 \mathrm{ml}$. The results were calculated from a standard curve standardized with soybean Lipoxygenase EC 1.13.11.12 Type V (Sigma-Aldrich). LOX activity was expressed as $\mathrm{U} \mathrm{mg}^{-1}$ protein.

\section{Statistical analysis}

The obtained results were elaborated using a one-way factorial analysis of variance (ANOVA 1) separately for harvest and after storage. The significance of difference between means was tested using Tukey's honestly procedure at $\alpha=0.05$.

\section{RNA isolation and RT-PCR analysis}

The RNA was extracted, as described by Zeng and Yang (2002), and quantified spectrophotometrically. Reverse transcription reactions were carried out as recommended by the manufacturer (Reverse Transcription System, Promega). The products of reverse transcription were used as templates for PCR analysis. The presence of genes encoding lipoxygenase in all cultivars was confirmed by a polymerase chain reaction (PCR) with a primer pair: 1F CTTTCATGTATGAAGAGTTGGA, 1R ACCCTTCTGCTGGAGTCT. Cycle number and primer hybridization temperature - essential for PCR gene amplification - were 28 cycles at $37^{\circ} \mathrm{C}$.

\section{RESULTS}

\section{Calcium content}

The fruits of the studied cultivars differed significantly in their calcium content (Tab. 2). Bitter pit-resistant cultivars revealed the calcium content in the range of 571 ('Gloster') to 705 ('Gala') $\mu \mathrm{g} \mathrm{g} \mathrm{g}^{-1}$ d.m. after harvest, and a considerable decrease of calcium after long storage was expressed only in the 'Gala' and 'Idared' apples. Calcium content at harvest in bitter pit-susceptible cultivars varied between 451 ('Ligol') and 669 ('Mutsu') $\mu \mathrm{g} \mathrm{g}{ }^{-1}$ d.m. After storage, the lowest concentration of Ca was exhibited by 'Ligol' with bitter pit and the highest in 'Alwa' apples. Symptoms of bitter pit were observed only in fruits of the susceptible cultivars. Ca content determined in the 'Šampion', 'Ligol', 'Mutsu', and 'Cortland' fruits with bitter pit was reduced up to $38.3 \%$ as compared to fruits of the same cultivar, but with no signs of bitter pit.

\section{Potassium content}

The potassium content in both sampled times was nearly the same, on average: 17.4 and $16.7 \mathrm{mg} \mathrm{g}^{-1} \mathrm{~d} . \mathrm{m}$., respectively (Tab. 2). The concentration of potassium ranged from 12.9 ('Cortland' with bitter pit after long term cold storage) to 19.5 ('Gloster' at harvest), respectively.

\section{Ratio K:Ca}

The mean of the $\mathrm{K}$ to $\mathrm{Ca}$ ratio was 33.2. The highest value of this parameter was displayed by 'Ligol' (with bitter pit in fruits after storage), whereas the lowest one was characterized by 'Alwa' apples at harvest. The K to Ca ratio, equalling 28.8 on average, was noted at harvest in cultivars without symptoms of bitter pit. Four months of cold storage influenced the $\mathrm{K}: \mathrm{Ca}$ ratio; however, this effect was highly cultivar-dependent. The highest decrease in the $\mathrm{K}: \mathrm{Ca}$ ratio was noted for the 'Gloster' 
Table 2. The concentration of potassium and calcium in fruits and $\mathrm{K}: \mathrm{Ca}$ ratio depending on the cultivar and the time of analysis

\begin{tabular}{|c|c|c|c|c|c|c|}
\hline \multirow[b]{2}{*}{ Cultivar } & \multicolumn{2}{|c|}{$\mathrm{K}\left(\mathrm{mg} \mathrm{g}^{-1}\right.$ d.m. $)$} & \multicolumn{2}{|c|}{$\mathrm{Ca}\left(\mathrm{mg} \mathrm{g}^{-1}\right.$ d.m.) } & \multicolumn{2}{|c|}{$\mathrm{K}: \mathrm{Ca}$ ratio } \\
\hline & At harvest & $\begin{array}{l}\text { After long-term } \\
\text { cold storage }\end{array}$ & At harvest & $\begin{array}{c}\text { After long-term } \\
\text { cold storage }\end{array}$ & At harvest & $\begin{array}{l}\text { After long-term } \\
\text { cold storage }\end{array}$ \\
\hline 'Idared'’ & $16.1 b^{*}$ & $16.9 \mathrm{ab}$ & $0.638 \mathrm{ab}$ & $0.567 \mathrm{bc}$ & $25.2 \mathrm{~d}$ & $29.9 \mathrm{~cd}$ \\
\hline 'Alwa' & $14.8 \mathrm{~b}$ & $16.9 \mathrm{ab}$ & $0.700 \mathrm{a}$ & $0.728 \mathrm{a}$ & $21.2 \mathrm{~d}$ & $23.3 \mathrm{~d}$ \\
\hline 'Gala'’ & $18.0 \mathrm{ab}$ & $18.7 \mathrm{a}$ & $0.705 \mathrm{a}$ & $0.565 \mathrm{bc}$ & $25.6 \mathrm{~d}$ & $33.2 \mathrm{bc}$ \\
\hline 'Gloster' ' & $19.5 \mathrm{a}$ & $18.2 \mathrm{a}$ & $0.571 \mathrm{ab}$ & $0.604 \mathrm{~b}$ & $34.3 \mathrm{bc}$ & $30.0 \mathrm{~cd}$ \\
\hline 'Ligol' & $16.8 \mathrm{ab}$ & $18.1 \mathrm{a}$ & $0.451 \mathrm{bc}$ & $0.468 \mathrm{bc}$ & $37.2 \mathrm{~b}$ & $39.1 \mathrm{~b}$ \\
\hline 'Mutsu'² & $18.6 \mathrm{ab}$ & $17.7 \mathrm{a}$ & $0.669 \mathrm{ab}$ & $0.571 \mathrm{bc}$ & $27.9 \mathrm{~cd}$ & $30.9 \mathrm{c}$ \\
\hline 'Cortland'² & $17.6 \mathrm{ab}$ & $18.1 \mathrm{a}$ & $0.643 \mathrm{ab}$ & $0.658 \mathrm{ab}$ & $28.1 \mathrm{~cd}$ & $27.9 \mathrm{~cd}$ \\
\hline ‘Šampion’3 & nd & $15.1 \mathrm{ab}$ & nd & $0.431 \mathrm{c}$ & nd & $35.0 \mathrm{bc}$ \\
\hline Average & 17.4 & 16.7 & 0.583 & 0.513 & 31.8 & 34.7 \\
\hline
\end{tabular}

*Means followed by the same letter do not differ significantly at $\alpha=0.05$

nd - lack symptoms of bitter pit on the fruits in orchard

${ }^{1}$ cultivars resistant to bitter pit

${ }^{2}$ cultivars susceptible to bitter pit but without symptoms

${ }^{3}$ cultivars susceptible to bitter pit with symptoms

Table 3. LOX activities in fruits and mean weight of fruit depending on the cultivar and the time of analysis

\begin{tabular}{|c|c|c|c|c|}
\hline \multirow[b]{2}{*}{ Cultivar } & \multicolumn{2}{|c|}{ LOX activities ( $\mathrm{U} \mathrm{mg}^{-1}$ protein) } & \multicolumn{2}{|c|}{ Mean weight of fruit $(\mathrm{g})$} \\
\hline & At harvest & $\begin{array}{l}\text { After long-term } \\
\text { cold storage }\end{array}$ & At harvest & $\begin{array}{c}\text { After long-term } \\
\text { cold storage }\end{array}$ \\
\hline 'Idared' 1 & $0.93 \mathrm{bc} *$ & $0.48 \mathrm{c}$ & $188.4 \mathrm{f}$ & $176.4 \mathrm{f}$ \\
\hline 'Alwa' ' & $1.09 \mathrm{bc}$ & $0.32 \mathrm{c}$ & $209.4 \mathrm{e}$ & $239.8 \mathrm{~d}$ \\
\hline 'Gala' ' & $2.45 \mathrm{a}$ & $0.70 \mathrm{bc}$ & $184.1 \mathrm{f}$ & $164.6 \mathrm{f}$ \\
\hline 'Gloster' ' & $1.00 \mathrm{bc}$ & $0.44 \mathrm{c}$ & $271.1 \mathrm{c}$ & $253.2 \mathrm{~d}$ \\
\hline 'Ligol' 2 & $1.00 \mathrm{bc}$ & $0.48 \mathrm{c}$ & $311.7 \mathrm{~b}$ & $198.1 \mathrm{e}$ \\
\hline 'Mutsu' 2 & $0.78 \mathrm{c}$ & $0.28 \mathrm{c}$ & $349.8 \mathrm{a}$ & $282.8 \mathrm{c}$ \\
\hline 'Cortland' ${ }^{2}$ & $1.24 \mathrm{~b}$ & $0.48 \mathrm{c}$ & 202.9 ef & $202.0 \mathrm{e}$ \\
\hline ‘Šampion’’3 & nd & $1.17 \mathrm{a}$ & nd & 346.9 a \\
\hline Average & 1.2 & 0.6 & 240.8 & 237.4 \\
\hline
\end{tabular}

*Explanations: see Table 2

(12.4\%), followed by 'Šampion' (8.6\%) and 'Cortland' $(0.6 \%)$. In the case of the other cultivars, an increase of $\mathrm{K}$ to $\mathrm{Ca}$ was observed. The mean $\mathrm{K}: \mathrm{Ca}$ ratio in cultivars without symptoms of bitter pit (after storage) was 33.4, while it rose to 43.3 in the fruits of the same cultivars but with bitter pit.

\section{LOX activity and fruit weight}

The mean fruit weight varied between $164.6 \mathrm{~g}$ ('Gala') and $349.8 \mathrm{~g}$ ('Mutsu') (Tab. 3). The mean fruit weight of cultivars with symptoms of bitter pit was significantly higher than for the same cultivars without bitter pit.

At harvest, LOX activity varied between 0.78 and $2.45 \mathrm{U} \mathrm{mg}^{-1}$ protein (Tab. 3). After four months of storage this value decreased 2.75 times in apples not displaying signs of bitter pit, on average. The occurrence of this physiological disorder was accompanied by a $40 \%$ increase of lipoxygenase activity. The lowest LOX activity was recorded for the 'Mutsu' cultivar without 




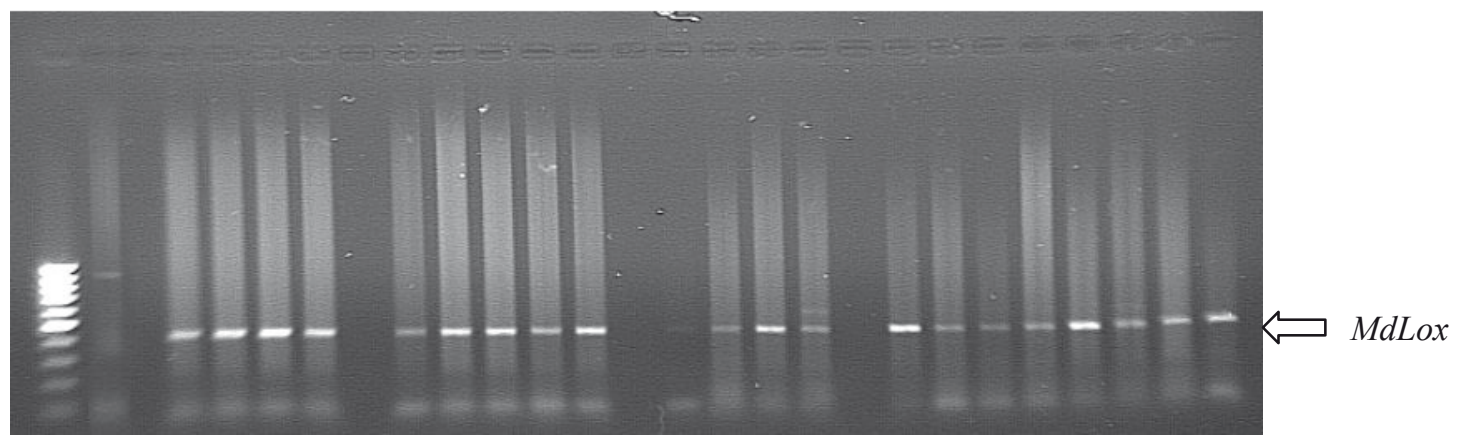

Figure 1. Lipoxygenase gene expression in various fruit developmental stages analysed by RT-PCR; PC) Positive control - polyA. 1) 'Alwa', 2) 'Gloster', 3) 'Gala', 4) 'Idared', 5) 'Šampion', 6) 'Ligol', 7) 'Mutsu', 8) 'Cortland', 9) 'Cortland' with bitter pit, 10) 'Alwa', 11) 'Gloster', 12) 'Gala', 13) 'Idared’; 14) 'Šampion', 15) 'Ligol', 16) 'Mutsu', 17) 'Cortland', 18) ‘Šampion’ with bitter pit, 19) 'Ligol' with bitter pit, 20) 'Mutsu' with bitter pit, 21) 'Cortland' with bitter pit, 2-9) - after harvest; 10-21) - after long-term storage under standard conditions; amplification was performed with a $1 \mathrm{~F}$ and $\mathrm{R}$ primers pair

bitter pit after long term cold storage, and the highest for 'Gala' apples analysed at harvest.

A significantly negative correlation was found between the Ca content and LOX activity $(\mathrm{R}=-0.55)$. The negative correlation coefficient increased after storage $(\mathrm{R}=-0.66)$. A negative correlation was also found between apple weight and LOX activity in all of the studied cultivars $(\mathrm{R}=-0.34)$. A positive correlation between $\mathrm{K}$ to Ca ratio and LOX activity $(\mathrm{R}=0.39)$ was recorded.

\section{Expression and nucleotide sequence of $L O X$}

Expression of MdLOX measured as the amount of mRNA depended on the cultivar and sampling time (Fig. 1). It was higher in fruits analysed immediately after harvest compared to fruits subjected to four months of storage. An increase of the lipoxygenase gene transcript in fruits with bitter pit, as compared to the same cultivar without signs of bitter pit, was noted. Compared to LOX activity, there were no evident differences in the case of pattern expression of gene-encoded LOX and only a few examples ('Šampion' at harvest with a lower expression, and 'Mutsu' with a higher expression compared to LOX activity).

\section{DISCUSSION}

Bitter pit is one of the most common physiological disorders observed during storage. It is known that apple storability potential is influenced by the contents of calcium and potassium as well as their ratio. An insufficient calcium content causes bitter pit occurrence in apple fruits (Sadowski et al. 1967, Tomala and Sadowski 1989). The current study also revealed that cultivars with symptoms of bitter pit were characterized by a low calcium content ( $355 \mu \mathrm{g} \mathrm{g}^{-1}$ d.m.) and high LOX activity. LOX activity observed in fruits of the 'Šampion', 'Ligol', 'Mutsu' and 'Cortland' cultivars with visible signs of bitter pit was $38 \%$ higher than LOX activity of apples not expressing symptoms of bitter pit. The Ca content was also related to the fruit size: bigger fruits contained smaller amounts of calcium, what is explained as a result of its dilution.

Ratkowsky and Martin (1974) and Tomala (1995) proved in their experiments that apples with bitter pit symptoms contained more potassium than healthy ones. This relationship was not observed in the current study. Fruits of the 'Šampion', 'Ligol', and 'Mutsu' cultivars with bitter pit were characterized by a lower K content in comparison to the same cultivars without symptoms of bitter pit. Schumacher et al. (1978) stated that a high $\mathrm{K}: \mathrm{Ca}$ ratio (above 36 ) is a more important indicator of bitter pit occurrence than $\mathrm{K}$ concentration. That finding was supported by further observations by Schumacher (1982) and de Jager (1994). Here, fruits with symptoms of bitter pit showed a $\mathrm{K}$ :Ca ratio above 35 . It is noteworthy that in the bitter pit-free fruits of the 'Ligol' cultivar, that ratio was above 35 in both fruits sampled after harvest and after storage. Fruits of the same cultivar, but with developed symptoms of bitter pit, showed a $\mathrm{K}: \mathrm{Ca}$ ratio above 62. Clearly, this supports the previous findings of de Jager (1994) in different cultivars.

The increase in the $\mathrm{K}: \mathrm{Ca}$ ratio in fruits as well as the expression of bitter pit symptoms could be correlated with an increase of lipoxygenase activity during storage (Marcelle 1989). However, we observed this phenomenon only in fruits of the 'Šampion' cultivar. Moreover, due to the significant decrease of LOX activity $(59.4 \%$ on average) in all of the other cultivars tested, it must be 
considered that the period of storage was longer than in previous studies (four months vs. three months).

\section{CONCLUSIONS}

Cultivars without symptoms of bitter pit were characterized with higher calcium content as compared to cultivars expressing this disorder, and a decrease in LOX activity after storage. The expression of the LOXencoding gene in fruits was different and depended on the cultivars and sampling time. High LOX activity was assigned to low calcium content and high $\mathrm{K}$ :Ca ratio.

\section{ACKNOWLEDGEMENTS}

This research was financially supported by the European Commission, grant QLK5-CT-2002-01492.

\section{REFERENCES}

Chiu T.F., Bould C., 1977. Sand-culture studies on the calcium nutrition of young apple tree with particular reference to bitter pit. J. Hort. Sci. 52: 19-28.

Coccuci S., Arbuzzese A., Rizzi E., Mignani I., Poma Treccani C., 1990. Fruit development, calcium level and bitter pit in apple. Adv. Hort. Sci. 4: 147-150.

DE JAger A., 1994. Jak w Holandii wyznaczamy termin zbioru. Biul. Tow. Rozw. Sadów Karłowych. Sad Karłowy 3: 14-20.

Drazeta L., Lang A., Hall A.J., Volz R.K., Jameson P.E., 2004. Causes and effects of changes in xylem functionality in apple fruit. Ann. Bot. (Lond). 93(3): 275-82.

MarCELle R.D., 1989. Ethylene formation, lipoxygenase activity and calcium content in apple (cv. 'Jonagold'). Acta Hort. 258: 61-68.

RatKowsky D.A., Martin D., 1974. The use of multivariate analysis in identifying relationships among disorder and mineral element content in apples. Aust. J. Agric. Res. 25(5): 783-790.

Sadowski A., Kurowska-Lipniewska M., Ulejczyk M., 1967. Studia nad gorzką plamistością jabłek. Występowanie choroby na odmianie Piękna z Boskoop w zależności od niektórych cech indywidualnych jabłek. Zesz. Nauk. SGGW, Ogr. 4: 55-76.

SAure M.C., 1996. Reassessment of the role of calcium in development of bitter pit in apple. Aust. J. Plant Physiol. 23: $237-243$.
Schumacher R., 1982. Causes possibles des maladies physiologiques sur pommier. SB Bull. 5(1): 36-43.

Schumacher R., Fankhauser $\quad$ F., Stadler W., 1978 Mineralstoffgehalte und Stippeanfalligkeit von Äpfeln in Abhängigkeit von ihrer Ansatzstelle in der Baumkrone. Schweiz. Obst. Weinbau 114(11): 295-303.

Tomala K., 1995. Prognozowanie zdolności przechowalniczej i wyznaczanie terminu zbioru jabłek. Fundacja Rozwój SGGW. Warszawa.

Tomala K., Sadowski A., 1989. Some factors determining quality and storage ability of 'Spartan' apples. Variation of different characteristics due to the season. Fruit Sci. Rep. 162: 59-66.

ZeNG Y., YANG T., 2002. RNA isolation from highly viscous samples rich in polyphenols and polysaccharides. Plant Mol. Biol. Report. 20: 417a-417e.

\section{AKTYWNOŚĆ LIPOXYGENAZY, ZAWARTOŚĆ WAPNIA I POTASU A GORZKA PLAMISTOŚĆ PODSKÓRNA W OWOCACH WYBRANYCH ODMIAN JABŁONI}

Streszczenie: Zawartość wapnia, potasu oraz aktywność lipoksygenazy jak również ekspresja genu kodującego LOX w owocach odmian jabłoni podatnych na występowanie gorzkiej plamistości podskórnej i tych, u których objawy tej choroby nie występują były zróżnicowane. Owoce pobrano i analizowano bezpośrednio po zbiorze w sezonie 2004 oraz po długim przechowywaniu w chłodni zwykłej. Główną przesłanką badań było wyjaśnienie roli powyższych parametrów w przechowywaniu jabłek. Największe zróżnicowanie między badanymi odmianami odnotowano w przypadku aktywności LOX, zawartości wapnia, następnie stosunku $\mathrm{K}: \mathrm{Ca}$, a najmniejsze dla zawartości potasu. Owoce bez objawów gorzkiej plamistości podskórnej charakteryzowały się wysoką zawartością wapnia i spadkiem aktywności LOX po przechowywaniu. Wykazano negatywną korelację między aktywnością LOX a zawartością wapnia, oraz pozytywną korelację między stosunkiem K:Ca a aktywnością LOX.

Received May 7, 2009; accepted April 28, 2010 